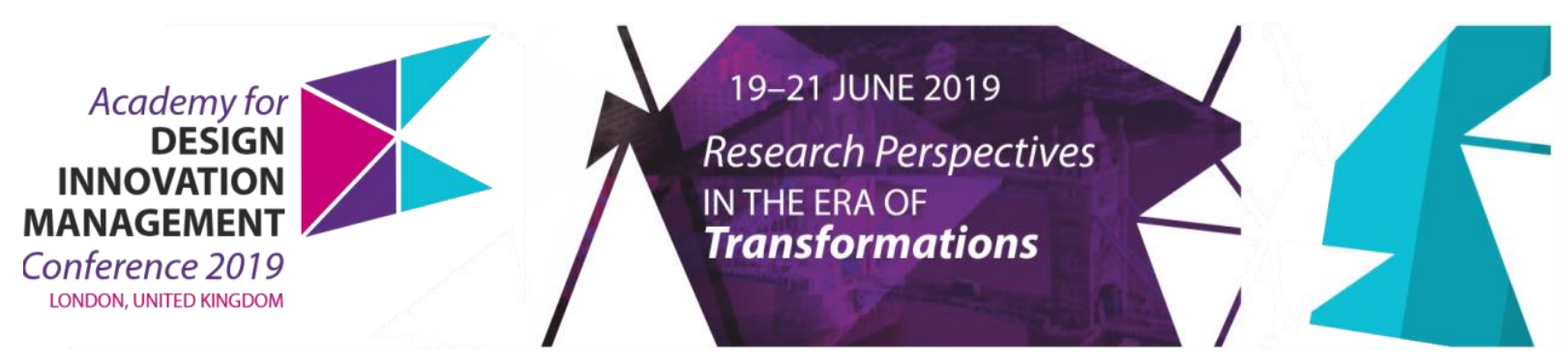

\title{
Track 5.j Introduction: Innovation Through Design for Meaning
}

\author{
AJOVALASIT Marco ${ }^{a}$; GIACOMIN Joseph ${ }^{\mathrm{b}}$; GKATZIDOU Voula ${ }^{\mathrm{b}}$ and JENSON BENNETT Julie ${ }^{\mathrm{c}}$ and PETTERSSON \\ Ingrid $^{\mathrm{d}}$ \\ a Politecnico di Milano, Italy \\ ${ }^{\mathrm{b}}$ Brunel University London, United Kingdom \\ 'Volvo Cars, Sweden \\ d Precipice Design, United Kingdom \\ doi: 10.33114/adim.2019.5j
}

This track brings together researchers and practitioners to share and discuss the approach, subsequent outcomes, contributions and possible futures of the design for meaning landscape.

For many fast moving consumer goods, home goods, office goods, vehicles, transport systems and elements of the built environment there are a growing number of instances in which a business opportunity can only be achieved by exploiting a new technology or a new cultural code (Holt and Cameron, 2010). Such cases of disruptive innovation or radical innovation are premised on the possibility of defining a new meaning for the potential consumers (Giacomin, 2017). The idea that design is a manner for making sense of things (Krippendorff,1989) is frequently discussed in professional circles, as is the idea that design involves doing philosophy with the hands (Wendt 2015). For many practicing designers the activity of design cannot be separated from the intended meanings of the artefact which is being designed.

Within market-driven economic systems the commercially active designers must consider the forms of value and meaning which a product, system or service may hold for its customers (McCracken, 1990). It is in fact frequently claimed that the meaning of a commercial offering is the actual basis of the business (Verganti, 2009). Experts from the branding sector usually concur, an often repeated statement being Aaker's (2002) proposition that "if a brand is "packaged meaning", a slogan can be the ribbon that ties the package together and provides an extra touch". The increased material wealth of industrialised societies has in recent years lead to debate about the meaning of designed artefacts, and about the role of meaning in the innovation processes of commercial enterprises. Numerous indicators point to a certain current glut of products, systems and services in people's lives, and to a trend of increased sophistication of selection on the part of the consumer (Wallman 2015).

Beyond the commercial considerations, it can also be suggested that consideration of target meanings is important towards defining the long term role which an artefact will play in the lives of its owners (Giacomin, 2017). The relational role of artefacts has been neatly expressed by Csikszentmihalyi and Rochberg-Halton (1981) as "the objects which people use, despite their incredible diversity and sometimes contradictory usage, appear to be signs on a blueprint that represent the relation of man to himself, to his fellows, and to the universe". In this view (see figure 3) artefacts are not simply functional tools, but are also relational mediators which shape the long term aims, objectives and behaviours of an individual or of a group.

Considering the importance of meaning in design it is perhaps surprising to note the frequent lack of clarity about these matters in design discussions and in design practice. In many websites, documents and publications of a commercial nature the word "meaning" is deployed without reference to the anticipated nature of the meaning and without reference to the individual involved. Further, semantics such as value, ideology, meaning, function, ritual, myth and metaphor are often used interchangeably, with important

This work is licensed under a Creative Commons Attribution-NonCommercialShare Alike 4.0 International License. https://creativecommons.org/licenses/by-nc-sa/4.0/ 
practical consequences in terms of possible misunderstanding. In the words of Sudjic (2008) "design is the language that a society uses to create objects that reflect its purposes and its values. It can be used in ways that are manipulative and cynical, or creative and purposeful. Design is the language that helps to define, or perhaps to signal, value". It would thus appear reasonable to ask that designers speak their language clearly.

The aim of this track is to encourage the discussion of design for meaning frameworks within businesses, including topics such as:

- developing and managing brands through meaning (paper 1);

- use of data, design ethnography, real fictions and co-creation to support innovation within design innovation teams (paper 2);

- $\quad$ the role of analogies, metaphors and meanings within business design innovation (paper 3);

- $\quad$ organisations and processes for achieving targeted design meanings (paper 4);

In the first paper, "Making Markets: The Role of Design in the Process of Legitimation", the authors examine the impact of design on the evolution of a product market from illicit to mainstream. The authors argue the importance of congruence with normative and cultural-cognitive structures in fostering legitimacy. By means of an ethnographic study of the newly-legal recreational cannabis market in the US, the authors analyse a market that has attained regulatory acceptance in some states but lacks normative and cultural-cognitive legitimacy. The authors offer a framework for managing products in new markets, arguing that design can enable legitimacy by drawing on symbolic relationships to other products, considering affordances, and enhancing strategic socio-cultural innovation.

In the second paper, "Meaning of artefacts: interpretations can differ between designers and consumers", the authors explore an important point in relation to the concept of "meaning" by which the meanings that become connected with products don't always have to be the meanings intended by the designers. Substantial divergences in meaning might be expected to lead to some degree of commercial difficulty at some point in an artefact's life cycle. Their research suggested that three primary categories of meaning which designers should consider during their design processes, i.e. function, ritual and myth, covering a spectrum from the purely instrumental to the purely symbolic, could be commonly encountered in practice, either individually or could be co-present to some degree. Their findings also suggest that some meaning divergences occur between designers and consumers, and would appear to highlight the need for carefully executed ethnographic and user testing activities.

In the third paper, "Design for Meaning of Smart Connected Products", the authors explore the topic of meaning-driven innovation from a Product Design perspective. It focuses on the design of Smart Connected Products: internet-enabled phygital products that blend hardware and software. Their work highlights three kinds of meaning that are relevant for Smart Connected Products: the meaningful identity of the object as product category, the meaning of the product in relation to its shape and functionality, and in relation to a phygital ecosystem. The paper reflects on the methods that can support designers in the development of meaningful smart products and presents the "Mapping the IoT" Toolkit, a downloadable tool that guides in specific activities aimed at framing the product's meaning.

In the fourth and last paper, "From Hype to Practice: Revealing the Effects of Al in Service Design", the authors discuss the current and even hyped topic of artificial intelligence (AI) in the context of service design. It takes in consideration the design principles for the context of artificial artefacts that are produced and consumed in a multi-user context supported by virtual environments and focus on the fact that design is 'language-like'. It also considers that with the shift towards the application of natural language processing (NLP) tools, services and products go beyond the conceptual and semiotic language. Their paper discusses not only what Al enables for the front and back ends of service delivery but also the practical role of the service designer and service design process in the context of Al-enabled services. The authors evaluate the datasets through coding cycles aiming at identifying the shifts $\mathrm{Al}$ brings to service design.

\section{References}

Aaker, D.A. 2002, Building strong brands, The Free Press, Simon \& Schusten Inc., London, UK.

Csikszentmihalyi, M. and Rochberg-Halton, M. 1981, The Meaning of Things, Cambridge University Press, Boston, Massachusetts, USA.

Giacomin, J. (2017). What is Design For Meaning. Journal of Design, Business \& Society, 3 (2), 167-190. 
DOI: $10.1386 / \mathrm{dbs} .3 .2 .167 \_1$

Holt, D. \& Cameron, D. (2010). Cultural strategy: using innovative ideologies to build breakthrough brands. Oxford University Press, Oxford, UK.

Krippendorff, K. 1989, On the essential contents of artifacts or on the proposition that "design is making sense (of things), Design Issues, Vol. 5, No. 2, Spring.

McCracken, G.D. (1990). Culture and Consumption: new approaches to the symbolic character of consumer goods and activities. Indiana University Press, Bloomington, Indiana, USA.

Sudjic, D., 2008, The Language Of Things: how we are seduced by the objects around us, Penguin Books, London, UK.

Verganti, R. 2009, Design-Driven Innovation: changing the rules of competition by radically innovating what things mean, Harvard Business Press, Boston, Massachusetts, USA.

Wallman, J. 2015, Stuffocation: why we've had enough of stuff and need experience more than ever, Crux Publishing, London, UK.

Wendt, T. 2015, Design for Dasein: understanding the design of experiences, CreateSpace Independent Publishing Platform, USA. 